\title{
Description of a New Species, Platynectes Sahyadriensis (Coleoptera: Dytiscidae), Predatory to Aedes Albopictus (Diptera: Culicidae) from the Foothills of Western Ghats, Kerala, India
}

\author{
Adil Bashir ${ }^{1 *}$, N Pradeep Kumar ${ }^{1}$ and Anisa B Khan ${ }^{2}$ \\ ${ }^{1}$ Vector Control Research Centre Field Station (ICMR), Kottayam, India \\ ${ }^{2}$ Department of Ecology and Environmental Sciences, Pondicherry University, India
}

Received: February 02, 2018; Published: February 16, 2018

*Corresponding author: Adil Bashir, Vector Control Research Centre Field Station (ICMR), Kottayam, India, Email: shah.adil333@gmail.com

\begin{abstract}
We describe a new species of Dytiscidae beetle belonging to the Genus Platynectes from the mid high land region of Kerala, on the foothills Western Ghats, India. Western Ghats is the second largest mountainous belt in India on the western side of the Deccan Plateau and is described as one of the eight "Hottest bio-diversities in the world". About $80.0 \%$ of rubber crop in the Country is cultivated in the mid high land region of Western Ghats in Kerala and its plantations had been recorded to be the important breeding grounds of Aedes Albopictus vector species. The new Dytiscid species has been reported to be an efficient natural predator of Ae. albopictus immature in their key breeding habitats. Morphological characters of both male and female specimens of the beetle are described. Its morphologic characteristics precisely matched with the genus Platynectes. The specimens were taxonomically characterized to be a new species under the genus Platynectes by the Natural History Museum, London (NHM). Voucher specimens of the species are deposited with the museum of NHM, London and the Vector Control Research Centre (ICMR), Puducherry, India. Since the holotype of the species had been recorded from Western Ghats region of Kerala state ("Sahyadri" in vernacular name), India, we name the new species reported as "Platynectes sahyadriensis".
\end{abstract}

Keywords: Platynectes; New species; Rubber plantation; Western Ghats; India

Abbreviations: NHM: Natural History Museum; UNESCO: United Nations Educational scientific and Cultural Organisation; FLCCs: Fixed Latex Collection Containers; DLCCs: Discarded Latex Collection Containers; LAS: Leica Application Suite

\section{Introduction}

Western Ghats is the second largest mountainous region of India, after the Himalayas (Anaimudi - $2694 \mathrm{~m}$ ). Ever green rainforests constitute $40.0 \%$ of the Western Ghats with a mean altitude of more than $900 \mathrm{~m}$ MSL. The rest of the area different types of plantation crops such as rubber, arecanut, cardamom, pineapple, nutmeg, pepper etc. are cultivated. United Nations Educational scientific and Cultural Organisation (UNESCO) inscribed Western Ghats as one of the Worlds Natural Heritage in India [1], and it is one of the eight hottest hotspots of biodiversity globally and has over 5000 species of flowering plants, 139 mammal species, 508 bird species, 179 amphibian species, it is likely many undiscovered species in this range, 325 globally threatened species [2]. The range runs north to south, along with the western edge of Deccan plateau of India and separates the plateau from a narrow coastal plain, called Konkan along the Arabian Sea. Kerala state, with a total area of 3.84 lakh hectares under rubber plantations and an annual production of 3.70 lakh tonnes, produces over 90\% of India's natural rubber.

Aedes Albopictus (Skuse) 1894 (Diptera: Culicidae), the predominant, species in Kerala has been recorded as the vector species of both these arbo-viral diseases dengue and chikungunya $[3,4]$. The key breeding habitats of this species are the rain water collections in the innumerable discarded (DLCC) and fixed (but unused) (FLCC) rubber latex collection containers, tree holes, leaf axils in pine-apple plantations, fallen leaves of areca-nut plantations etc. in the plantation sector of Kerala [5]. During the Chikungunya outbreak in 2007-2010, in Kerala, $63 \%$ of the population was affected by this disease in the rubber plantations, and Ae. albopictus acted as the main vector species. While carrying out investigations to elucidate the epidemiological and entomological factors involved in the outbreak of chikungunya/dengue fevers in the rubber 
plantation region of Kerala, we came across the occurrence of a predacious diving beetle in the water holding Fixed Latex Collection Containers (FLCCs) and Discarded Latex Collection Containers (DLCCs), in one of the villages, Aimcompu (09 $46.30^{\prime} \mathrm{N} ; 760$ 41.23’E), in Kottayam district during 2008-2010.

The Coleopteran beetle was taxonomically identified as Platynectes sp. nov. (Family: Dytiscidae) by the Natural History Museum, London (Figure 1). Further, field investigations revealed natural occurrence of this species in other rubber plantation areas, selected for the entomological surveillance programs, viz., Pampady (090 33.98' N; 760 38.64' E) in Kottayam District and Chethackal (090 25.31' N 760 48.43' E) in Pathanamthitta District. Hence, we carried out a scientific and systematic study to determine the taxonomical identification of genus Platynectes as a new species. Predatory habit of the newly described species of Platynectes on immature of Aedes albopictus, the vector on dengue and chikungunya in rubber plantations has been described elsewhere [6]. Natural Prevalence and population density of the beetle has been also recorded for a period of year in the fixed and discarded latex collection containers in the rubber plantations. The average prevalence rate $(22.68 \%$ ) and density (2.23 per latex collection container) of the beetles were found to be maximum during September (South West Monsoon season).

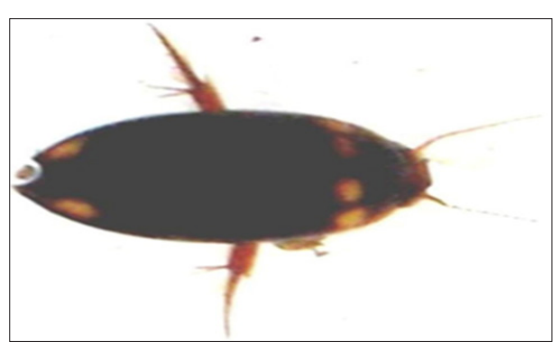

Figure 1: Platynectes sp. Nov.

Beetles were not found prevalent in the containers from January to April. The re-occupation of beetle in containers starts during the month of May, when intermittent rainfall ensued prior to the onset of monsoon season. Prevalence of Platynectes species had been already reported in the Himalayan region [7]. Taxonomically these were characterised to be Platynectes kashmiranus (Jammu and Kashmir, Punjab, Manipur, Assam and Nepal) and Platynectus coriacous (Assam and Khasi hills). However no Platynectes species has been recorded elsewhere in the country. The present study reports the prevalence of new species of Platynectes from rubber plantations located at the foot hills of Western Ghats region of Kerala (hottest biodiversity spot, UNISCO) and is described with illustrations and taxonomic position in this communication.

\section{Materials and Methods}

The study was carried in rubber plantation sectors Aimcompu $\left(09^{0} 46.30^{\prime} \mathrm{N} ; 7604.12^{\prime} \mathrm{E}\right)$, in Kottayam district, (090 33.91' N; $76038.6^{\prime}$ E) in Kottayam District and Chethackal (090 25.30' N, $76048.48^{\prime}$ E) in Pathanamthitta District. These villages constitutes large scale rubber plantations, contributes $90 \%$ land for rubber production. The plantation sector supports great varieties of vegetation, rubber, arecanut, cardamom, pineapple, nutmeg, pepper, and streams, permanent and temporary pools along the Western Ghats. The innumerable containers are used to collect the latex from rubber trees throughout the plantations, fixed with rubber trees known as Fixed Latex Collection Containers (FLCCs) and discarded on the ground especially during the rainy seasons known as Discorded Latex Collection Containers (DLCCs), as rain gets collects in these containers, become the major breeding habitats of Ae. albopictus major vector of Chikungunya and Dengue arboviral diseases. The described Platynectes sp. nov has been found natural predator of immature of Ae. albopictus in the plantations and is naturally prevalent in the fixed and discarded latex collection containers throughout plantation sectors during the breeding season of Aedes mosquitoes.

\section{Platynectes collection}

Platynectes species were collected from temporary and permanent pools, fixed and discarded latex collection cups prevalent in the rubber plantation sectors along with the immature of $A e$. albopictus and were transported to laboratory at the VCRC field station Kottayam Kerala for examination. Platynectes species were placed in the enamel trays along with fresh water and fed with Aedes larva for some days before examine the specimens. The specimens were kept in -400C freezer for dyeing 20-30 minutes, immediately specimen were transferred $70 \%$ alcohol for preservation and were examined under stemi- DV4 Zeiss stereomicroscope for external morphological characteristics. The specimens were also dissected under the same microscope for anatomical characteristics and were mounted on microscopic slides, using Hoyer's medium and microscopic cover slips and has been identified up to species level examining under Olympus binocular compound-microscope (Model CHS, Olympus Optical Co Ltd, made in Japan), male and female difference of external parts as well as internal parts were also examined under the same microscope at $40 \mathrm{X}$ magnification. On the basis of internal morphology male and female are separated and both the sexes of this group were distinct from other Platynectes species.

Photographs of morphological and anatomical features of both male and female specimens were taken using Leica Application Suite (LAS) version 3.8.0. (build 878) compound microscope at $40 \mathrm{X}$ magnification, zoom $1-2 \mathrm{X}$ and 50 um length fixed with microscope. The measurements of body length and body width were also taken by micrometer fitted with stemi 20000-C stereomicroscope (Carl Zeiss) and were recorded in $\mathrm{mm}$. The specimens used for morphometric measurements and dissection include holotype, allotype and paratype. Each of the holotype, paratype and allow type were mounted on microscopic glass slides, using semipermanent Hoyer's medium. Terminology of the characteristics adopting for description followed by [8-13].

\section{Results}

\section{Platynectes sp. Nov}

a) Holotype: Male specimen of the species was collected from the fixed latex collection containers at Aimcompu (Kottayam 
District, Kerala, India) rubber plantation located at the foot hills of Western Ghats $\mathrm{N}=09^{\circ} 46.30, \mathrm{E}=76041.21^{\prime}$ within altitude of $63.8 \mathrm{~m}$ on $10^{\text {th }}$ July 2011.

b) Allotype: Also female specimen of the species was collected from fixed latex collection containers at aimcompu rubber plantations $\mathrm{N}=09^{\circ} 46^{\prime} 45.9, \mathrm{E}=076^{\prime}$ 41'33.6' within altitude of $40 \mathrm{~m}$.

c) Paratype: Subquently male specimens were collected from following locations: Kalaketty (Kottayam District, $\mathrm{N}=09$ 26.412, $\mathrm{E}=76^{\prime}$ 56.428, altitude=324.1, m). Kanamale, (Kottayam District, N=090 26.583', E=76' 56.29, altitude=307.7 m.) Anakkal, (Kottayam District, N=090 34.489', E=76 46.983, altitude $=319.6 \mathrm{~m}$ ). Chethackal (Pathanamthitta District, $\mathrm{N}=090$ $2.53^{\prime} \mathrm{E}=760$ 4.84' E, altitude= 69) Makkuttathara, (Kottayam
District N=09 26.372, E=076 53.736, altitude=748.4,) (5) Pambavalley, (District Kottayam N=09 25.675, E=076 56.465, altitude $=731.8$ ) (6) Palaparanbil, (District Kottayam, N=090 32.986, E=0760 52.619, altitude=380.2), Malankara (District Idukki, N=090 51.35, E=0760 44.42, altitude=48 m). Paratype: Female specimens were collected following locations: (1) Kalaketty, (Kottayam District N=09 26.296, E=076 56.279', altitude=732.2 m), Kanamala ,(Kottayam District N=09 26.497, $\mathrm{E}=076$ 56.315, altitude=324.7 m), Palampara, (Kottayam District $\mathrm{N}=09$ 34.826, $\mathrm{E}=076$ 49.624, altitude=297.8 m), Mookanpetty,(Kottayam District N=09 25.303, E=076 56.423 m, altitude=323.9), Anakkal, ( Kottayam District N=09 34.489, $\mathrm{E}=76$ 46.983, altitude=319.6 m), Palakal, (Kottayam District $\mathrm{N}=09$ 26..638, E=076 53.588, altitude 366.7), Malankara (District; Idduki N=09 51' 35', E=076 44. 42', altitude=41 m).

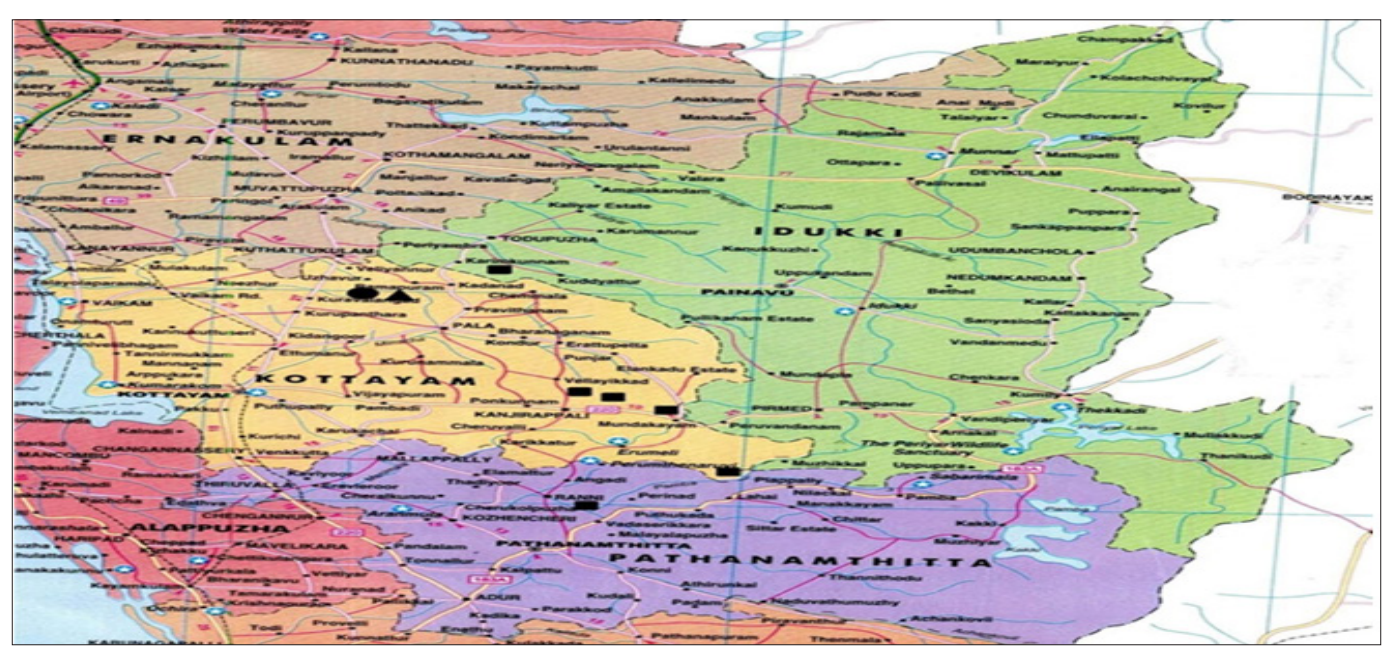

Figure 2: Localities from where Holotype, Allotype and Paratype were collected.

The localities from where Holotype, Allotype and Paratype were collected are given in the map (Figure 2). General colour of beetle is blackish-yellow. Body size $5 \mathrm{~mm}$. Width is $2.50 \mathrm{~mm}$, Head length 0.40 $\mathrm{mm}$, width $1.0 \mathrm{~mm}$. Pronotum length is $0.50 \mathrm{~mm}$, width $1.40 \mathrm{~mm}$. Maxilla length is $0.5 \mathrm{~mm}$, Mandible length $0.2 \mathrm{~mm}$ Antennae length is $1.20 \mathrm{~mm}$, antennomers eleven in number. Head reddish- brown, near the eyes blackish. Ventral side of mouth and head are reddishbrown, antennae yellow to yellowish brown, mandibles, maxillary and labial palps are yellowish-black, eyes black. Pronotum reddish black at middle and yellow to yellowish brown at edges from anterior to posterior margins. Mesoscutellum triangular in shape, piceous in colour Elytra length $4.1 \mathrm{~mm}$, width $2.5 \mathrm{~mm}$. Anterior side broad and posterior pointed, black with yellowish eight spots from anterior to posterior margins forming somewhat yellowishblack, four spots at anterior side just below the anterior margins of elytra, two on each elytra left and right, two at the middle-lateral of elytra not seen by naked eye, two at the posterior-lateral margin of elytra. The posterior margin tip of elytra is somewhat yellowishblack. Femer length is $1.20 \mathrm{~mm}$, Tibia length $1.10 \mathrm{~mm}$, Tarsia length is $1.50 \mathrm{~mm}$, tarsomeres: T1 $0.50 \mathrm{~mm}, \mathrm{~T} 20.30 \mathrm{~mm}$, T3 $0.20 \mathrm{~mm}, \mathrm{~T} 4$ $0.20 \mathrm{~mm}$, T5 $0.30 \mathrm{~mm}$. Ventral surface and femer of legs testaceous. Tibia and tarsai having reddish-black. Median lobe of aedeagus length $.6 \mathrm{~mm}$, Parameres length $0.50 \mathrm{~mm}$, Female genitalia length $1.20 \mathrm{~mm}$. The morphometric features showed similarities in both the sexes. However morphologically male having fore tarsi widened and length of the spines at tarsal segments of male is little longer than female (Figure 3).

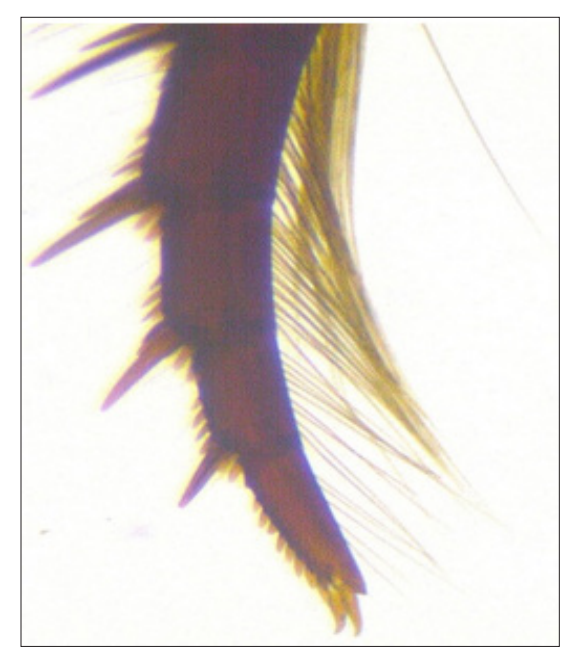

Figure 3: Spines of male tarsal segments. 


\section{Diagnosis}

The features of black prontoum and elytra with contrasting yellow markings or spots include eight to ten elytra spots on the specimens exactly match with the taxonomical characters of the genus Platynectes. Also metacoxal lines abridged anteriorly, not reaching the posterior border of metasternum/metaventrite / posterior pronatal acute is the character of subgenera Gueorguievtes. Elytra having eight yellow spots, protarsia of male expanded into widened, posterior margin rounded, and metacoxal line raised, well separated. General appearance of beetle is dark, epipleuron black Eight yellow spots on the elytra (six spots visible to naked eye and two spots visible microscopically) were found in both the sexes Body elongate-oval shaped. Head and pronotum surfaces are smooth without any irregular meshes and punctuations, no reticulation. Antennae filiform, Pronotum shiny and posterior angles are acute. Eyes with anterior margin above the base of antennae, emarginated.

Elytra having irregular meshes and punctuations from anterior to posterior margins, no micro-reticulations are visible. Mesoscutellum is formed at the junction of elytra at middle of anterior side. Metasternal wing very narrow laterally. Femur of the fore-legs and tibia of the mid-legs having little setae present in both male and female. The tarsals of the hind- legs of both male and female having longer setae. Spines of tarsals at each of the fivesegments are little longer in males than females. Pro, meso and metatarsomeres with claws, equal in length. Abdomen ventries six in number, horizontally present in both the sexes. Epipleura gets much narrowed at the level of the first abdomen segment. Posterior margin bordered and broadly rounded, metacoxal lines raised, well separated a little divergent at anterior in both the sexes. Claw of the both sexes are equal in length in all the three pairs of legs, as shown in Figure 4.

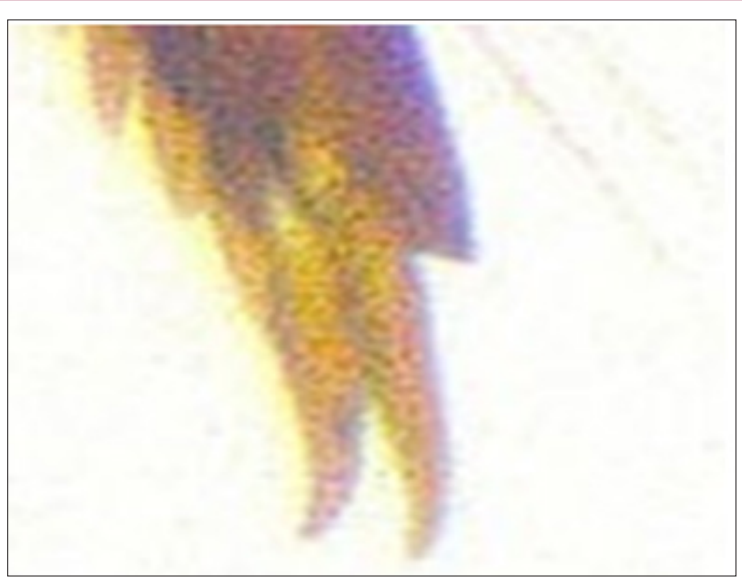

Figure 4: Claw of Platynectes sp. nov.

a) Male: Protaromers little expanded into 3 protarsus widened, but not forming ovale or circular disc and moderately clothed with setae ventrally (Figure 5). Aedeagus in lateral view regularly curved, evenly tapped, broadened at middle, rounded at apex, hook like at the base. Aedeagus greyish in colour, transparent at base and tip of the base is blackish (Figure 6).

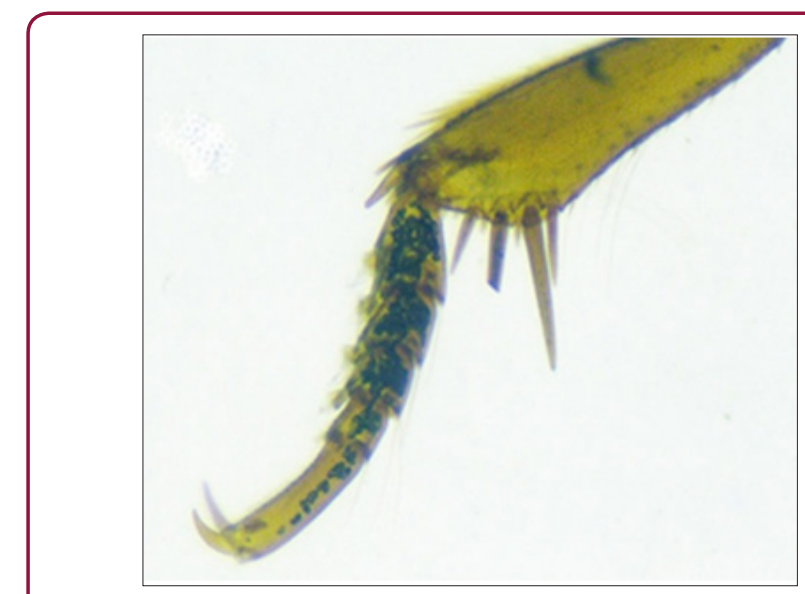

Figure 5: Male protarsomeres.

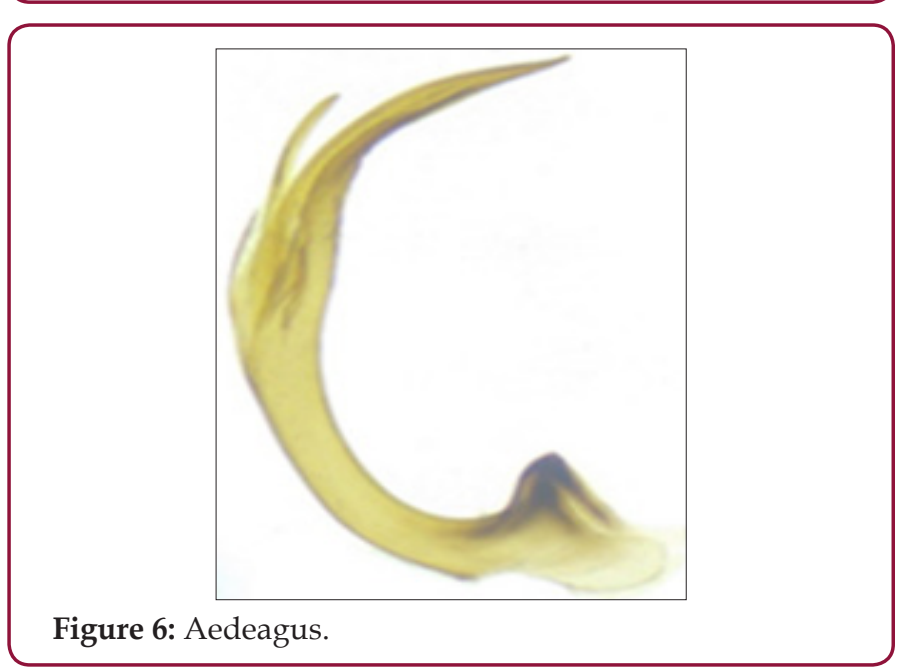

b) Female: Protarsomeres not expanded into four protarsus widened or ovule. Genitalia are greyish in colour and longer in shape, inner side with long hairs. The length of Spines of tarsal segments are more of less little than male.

\section{Bionomics}

The species of the both proliferate and breed fresh water permanent and temporary pools and streams found in the rubber plantations of Kerala. They preferred to rest under vegetation leaves and base of the latex collection containers, protect themselves from direct light. The climate with high rainfall and cool temperature also with abundant vegetation and different plantations was found for survival of the species. They were found in latex collection containers where Aedes mosquitoes breed and devour the immature instars profusely.

\section{Etymology}

The holotype allotype and paratype specimens were obtained from rubber plantations of Western Ghats which are located in different district Kottayam, Idukki, Pathanamthitta, in Kerala. The species was assigned a new name Platynectes "sahyadriensis" in recognition of area/state from where it was collected for the first time based its in the breeding habitats of the Aedes albopictus/ aegypti prevalence. 


\section{Discussion}

Genus Platynectes was taxonomically described initially as Genus Colymbatus for this genus. In 1857 Gistel proposed the name of the genus could be Plateocolymbus. In 1879 Regimbart separated a new genus from the genus Agabus which included species from South America, Australia and New Zealand including Colymbatus lineatus and named it as Platynectes, he also separated eight species from genus Agabus and incorporated under the genus Platynectes, Sharp also accepted this view and included twenty one species under this genus. Later Balfour-Browne in 1944 named Platynectes lineatus to Platynectes kashmiranus [14]. Taxonomy of Genus Platynectes remained obscure and was revised recently by Nilsson, the genus Platynectes has been categorised into three subgenera: (a) Platynectes, which included Platynectes decmnotatus, kashmiranus and nigroangularis (b) Paraplatynectcs, which included Platynectes guttla and (c) NeoPlatynectes, which includes Platynectes princeps, coriaceus, and procerus.

Three species of this genus were reported to be prevalent in India viz; Platynectes kashmiranus, Platynectes coriaceous and Platynectes guttula. However according to the revised classification [15]. Genus has been divided into three subgenera: (a) Australonectes, which includes one species Platynectes brownie (b) Gueoguievtes, which includes thirty four species and (c) Platynectes Regimbart, which includes eleven species [15]. Totally forty six species were included under this genus. However only one species had been reported from India (Platynectes kashmiranus) so far according to this classification [15]. Platynectes species from neighbouring countries like china has been reported. Also the distribution of Platynectes species from South-East Asia has been recorded by many authors [16]. Platynectes species are known from South America, as well as the Oriental and Australasian Realms and were revised by Gueorguiev [16], revised the Oriental taxa of the Platynectes dissimilis-group. Some 17 species are known to occur in the Oriental Region [10]. Finally [17,18], revised the Platynectes of Laos and described two new species.

In 1978, Watts re-described all Australian species and added two new ones, one of which was later synonymised [19]. The genus is currently in need of a comprehensive revision and many species or subspecies especially in Melanesia are still unnamed. Some Australian species are comparatively characteristic and are readily identified. Others, which generally include the most abundant and widely distributed ones, are not. In many cases species identities, ranges, subspecies boundaries and colour variations are subject to confusion and misinterpretation [13]. In recent years the authors have studied all relevant type material of the Australian taxa in preparation of a taxonomic revision (Sastny et al. in prep.). Two species, $P$. javanus Nilsson and an unidentified species of the $P$. decempunctatus-group, are recorded from higher altitudes (above $1000 \mathrm{~m}$ ) in Malaysia. The Platynectes in the Palaearctic and the Oriental Regions constitute only subgenus Gueorguievtes with known 26 species [20]. The Palaearctic fauna is relevantly poor, several species inhabit a transition zoon in between the Palaearctic and the Oriental regions from Himalayas to south China and most species occur in the Oriental Region.
The subgenus Gueorguivetes is characterised by the hind metacoxal line being obsolete anteriorly and not reaching the hind margin of the metaventrite. It can be separated into two major groups [21]. Group one with posterior pronotal angle obtuse or rectangle and group two with posterior pronotal angle acute. Some species from group two were revised and this group is confined in the Oriental and Australian Regions, group one is distributed in the south eastern Palearctic Region and the northern part of Oriental Region. The Platynectes species described in this study belonged to Family: Dytiscidae, Subfamily: Colymbetinae, Tribe: Agabani Genus: Platynectes. We name the species described here as Platynectes "sahyadriensis" since it differs from all the reported species of genus Platynectes in the following characteristics as: Eight yellow spots on the elytra (six spots visible to naked eye and two spots visible microscopically) were found in both the sexes. Mouth and ventral side are brownish at except eyes. Pronotum simple black in colour at the middle, anterior and posterior angles brownish. It differs from Platynectes kashmiranus, which had been recorded from India, the only species of the genus Platynectes recorded from the Country in the following characters.

The Platynectes kashmiranus at anterior side of elytra without any spot and the border of elytra having eight lining or spots. In female's elytra is having small meshes of micro reticulations on later side with deep cuttings but are not longitudinally stretched. This species is closely related to other Platynectes species of the following characteristics and hence is grouped into the Genus Platynectes. The elytra sculpture irregular meshes, pronotum acute at posterior angles, and elytra having yellow spots and blakish in colour, protarsia of male expanded into widened, posterior margin rounded, metacoxal line raised, well separated [17]. Also the species is well characterised black epipleura, the characteristics of the Genus Platynectes Regimbart. The contrasting marking may be very successful adaptations for sunlit lotic habitats in the forest edges. On the other hand species living in the shaded forest streams are characterised by contrasting colouration consisting of eight to ten spots on the blsck ground [10]. We propose the utility of this newly reported species Platynectes sahyadriensis as an efficient biological control agent towards incorporation in the Integrated Vector Management strategies for arbo-viral disease vector control, in the affected rubber plantation regions of Kerala.

\section{Acknowledgment}

The authors acknowledge Natural History Museum, London (NMH) for the taxonomical characterization of the described Coleopteran species and to the Pondicherry University for providing Doctoral fellowship to the first author.

\section{References}

1. Lewis C (2012) 39 sites in Western Ghats get world heritage status, TNN. The Times of India.

2. Mayers N, Mittermeier RA, Mittermeier CG, Da Fonseca GAB, Kent J (2000) Biodiversity Hotspots for conservation priorities. Nature 403(6772): 853-858.

3. Kumar NP, Joseph R, Kamaraj T, Jambulingam P (2008) A226V mutation in virus during the 2007 chikungunya outbreak in Kerala, India. Journal of General Virology 89: 1945-1948. 
4. Thenmozhi V, Hiriyan JG Tewari SC (2007) Natural vertical transmission of dengue virus in Aedes albopictus (Diptera: Culicidae) in Kerala, a southern Indian state. Japanese Journal of Infectious Diseases 60(5): 245-249.

5. Kumar NP, Suresh A, Vanamail P, Sabesan S, Krishnamoorthy K et al. (2011) Chikungunya virus outbreak in Kerala, India 2007. A seroprevalence study. Memorias do Instituto Oswaldo Cruz 106(8): 912-916.

6. Kumar NP, Bashir A Abidha S, Sabesan S Jambulingam P (2014) Predatory potential of Platynectes species (Coleoptera: Dytiscidae) on Aedes albopictus, the vector of dengue/ chikungunya in Kerala, India. Tropical Biomedicine 31(4): 736-741.

7. Vazirani TG (1970) Contributions to the study of aquatic beetles (Coleoptera), A revision of Indian Colymbetinae (Dytiscidae). Oriental Insects 4(3): 303 -361.

8. Miller KB, Nilsson AN (2003) Homologyand terminology: Communicating information about rotated structures in water beetles. Latissimus 7: 1-4.

9. Zhao S, Jia F Balke M (2011) Rhantus fengi sp. n. from Xizang, China, and notes on Laccoporus nigritulus (Gschwendtner) (Coleoptera, Dytiscidae). Zookeys 96: 61 -71.

10. Hendrich L Balke B (2000) The genus Platynectes Regambart in the Moluccas (Indonesia) taxonomy faunistics and zoogeography Koleopterologische Rundschau70: 37-52.

11. Ribeiro Costa1 CS, Vieira MK, Manfio D, Kergoat GK (2014) A remarkable new species group of green seed beetles from genus Amblycerus Thunberg (Coleoptera, Chrysomelidae, Bruchinae), with description of a new Brazilian species. ZooKeys 401: 31-44.

12. Sastny J (2003) Dytiscidae: X Review of Platynectes subgen. Gueorguievtes Vazirani from Southeast Asia (Coleoptera). In: Jäch MA, J
L (Edn.), Water Beetles of China. Zoologisch-Botanische Gesellschaft in Österreich and Wiener Coleopterologenverein Wien, pp. 217-259.

13. Hendrich, L, Stastny J (2014) Taxonomic revision of Australian Platynectes Regimbart, 1879 (part I)-four new species from Queensland (Coleoptera: Dytiscidae), Agabinae. Zootaxa 3795: 25-37.

14. Nilsson AN (1993) Platynectes Regimbart, 1879 (Insect, Coleoptera): preposed conservation. Bulletin of Zoological Nomenclature 50(30): 212-214.

15. Nilsson AN (2014) A World Catalogue of the Family Dytiscidae, or the Diving Beetles, (Coleoptera, Adephaga).

16. Nilsson AN (1998) The genus Platynectes REGIMBART in China, with a revision of the dissimilis-complex (Coleoptera). Water Beetles of China 2: $107-121$.

17. Brancucci M (2008) The genus Platynectes Régimbart, 1879 in Laos, with the description of a new species (Coleoptera: Dytiscidae). Entomologica Basiliensia et Collectionis Frey 30: 21-25.

18. Brancucci M, Vongsana k (2010) Distributional notes on the genus Platynectes Regimbart, 1879, in Laos with the description of a new species (Coleoptera: Dytiscidae). Entomologica Basiliensia et Collectionis Frey 32: 1-6.

19. Watts, CHS (1978) A revision of the Australian Dytiscidae (Coleoptera). Australian Journal of Zoology Supplementary Series 26(57): 1-166.

20. Nilsson AN (2001) A World Catalogue of the Family Dytiscidae, or the Diving Beetles, Coleoptera, Adephaga.

21. Gueorguiev VB (1972) Notes sur les Agabini (Coleoptera, Dytiscidae). II. Revision des genres Platynectes Regimbart et Colymbinectes Falk. Izvestija na Zoologitjeskija Instituts Musei Sofia 34: 33-62.
This work is licensed under Creative Commons Attribution 4.0 License

Submission Link: http://biomedres.us/submit-manuscript.php

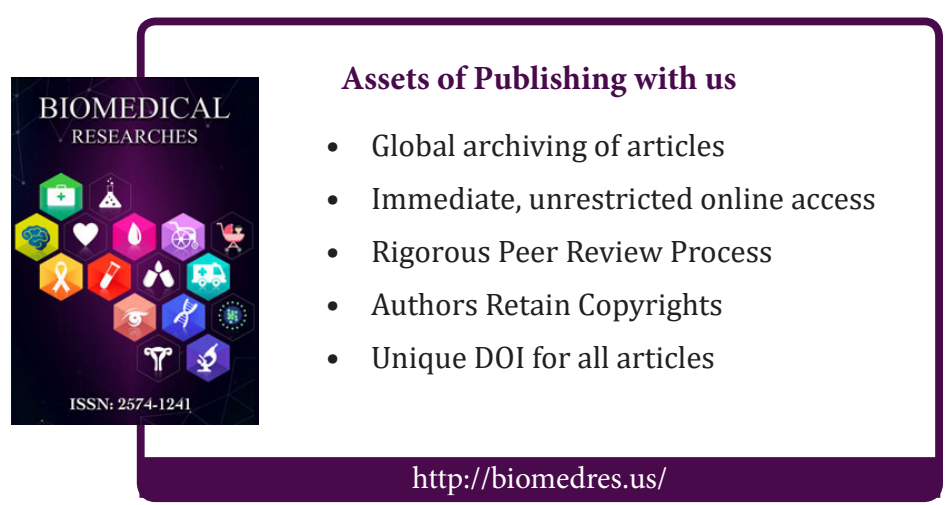

